\title{
Suppression and Enhancement of Secondary \\ Ion Formation Due to the Chemical \\ Environment in Static-Secondary Ion \\ Mass Spectrometry
}

\author{
Emrys A. Jones, Nicholas P. Lockyer, Jeanette Kordys, \\ and John C. Vickerman \\ Surface Analysis Research Centre, Manchester Interdisciplinary Biocentre, CEAS, University of Manchester, \\ Manchester, United Kingdom
}

Through analyzing mixtures of compounds of known gas-phase basicities, the importance of this property on the secondary ions emitted from a surface under primary ion bombardment is investigated. The aim is to obtain a greater understanding of the ionization mechanisms that occur in secondary ion mass spectrometry (SIMS). The commonly used matrix assisted laser desorption/ionization (MALDI) matrix 2,4,6-trihydroxyacetophenone (THAP) and a range of low molecular weight biomolecules were used to investigate whether analyte/matrix suppression effects that have been observed in analogous MALDI experiments were also present in static-SIMS. The outcome of the experiments demonstrates that strong suppression of the quasi-molecular signal of one molecule in a mixture can occur due to the presence of the other, with the gas-phase basicity of the compounds being a good indicator of the secondary ions detected. It is also demonstrated that the suppression of the quasi-molecular ion signal of a compound in a two-component mixture can be minimized by the inclusion of a third compound of suitable gas-phase basicity. (J Am Soc Mass Spectrom 2007, 18, 1559-1567) () 2007 American Society for Mass Spectrometry

S tatic-SIMS (S-SIMS) has become a well-established technique for obtaining chemical information from surfaces, with molecular mapping of biological samples being at the forefront of the current wide list of applications. The secondary ion yields from the compounds within these systems are generally very low, and initial work on cells and tissue sections were mainly limited to mapping phospholipid headgroups $[1,2]$, which produce a fragment ion that is very efficiently detected with SIMS. Recent developments such as commercially available cluster ion sources [3-5], and the sample pre-treatment techniques involving matrix addition [6] and metal deposition [7], have provided methods for increasing secondary ion yields from organic surfaces, and when applied to cells and tissue allow a greater wealth of information to be obtained [8-15]. However, as compounds of lower surface concentration become accessible to the SIMS technique, care must be taken that the results obtained are representative of the true distribution of the compound within the sample. Complex systems such as tissue contain different chemical domains, which may alter the ionization probability of a given compound. To

Address reprint requests to Dr. E. A. Jones, Surface Analysis Research Centre, Manchester Interdisciplinary Biocentre, CEAS, University of Manchester, 131 Princess St., Manchester M1 7DN, U.K. E-mail: emrys. jones@manchester.ac.uk avoid the misinterpretation of chemical distributions in such systems using SIMS requires the detailed understanding and, if possible, control of these effects.

The fact that the ionization of a molecule can be greatly affected by its chemical environment has been used in an advantageous way with matrix enhanced SIMS (ME-SIMS). Success has been achieved in generating the quasi-molecular ions from proteins up to 10 $\mathrm{kDa}$ [16], and with drug molecules and carbocyanine dyes [17]. Matrix addition has also aided in the imaging of peptides in tissue sections [8]. The use of a matrix to aid in the detection of the analyte has also been implemented in the related technique, laser desorption ionization (LDI). This approach proved so successful that the technique matrix assisted laser desorption/ionization (MALDI) [18-20] has now largely superseded LDI. However, in contrast to the laser based technique, the matrix in ME-SIMS does not cause a fundamental difference to the desorption process. In MALDI, the matrix acts as a resonant absorber for the photons, causing a phase explosion due to overheating of the surface, this leads to the ablation of massive amounts of material. In contrast, there is no evidence of greater efficiency of energy deposition caused by the presence of the matrix in a ME-SIMS event, and hence the yield enhancements seen must then be justified by other mechanisms. The logical conclusion is that the presence of the matrix in ME- 
SIMS provides an optimized surface chemistry for the formation of molecular ions. This could be attributed to the matrix acting as a source of protons, and/or forming a 'nestle environment' for the analyte [6]. ME-SIMS has also demonstrated lower fragmentation of the analyte molecules, thought to be due to a cooling effect, which removes the internal energy of the desorbed species and hence minimizes the probability that it fragments in the gas-phase [16].

As it is central to the technique, the interaction between matrix and analyte within MALDI analysis has been studied in detail. Although many primary ionization pathways have been identified [21], it is postulated that secondary processes that occur within the expanding plume of sputtered species are the most important factor when it comes to explaining the ions detected [22]. A model where a thermodynamic equilibrium is reached, resulting in an ion population determined by gas-phase chemistry, has been validated experimentally, with the gas-phase basicities of the molecules within the mixture used to successfully predict the outcome [23].

As SIMS is another desorption/ionization technique it could be postulated that similar factors govern the final population of detected ions. However, the major difference could be the most important- the size and density of the desorption plume. If a certain plume density is required for the effects to be seen, then the much smaller amount of desorbed material per event with SIMS as opposed to MALDI may mean the secondary events are not as significant. The sputter yield with SIMS has traditionally been low, with single ion impacts causing only tens [24] of secondary molecules to be desorbed, even the newly developed cluster ion beams such as $\mathrm{C}_{60}{ }^{+}$[5] only result in $\sim 2000$ ejected molecules from an ice surface [25]. This is in direct comparison to MALDI events, which have been shown to eject $10,000 \mu \mathrm{m}^{3}$ of material in a single IR laser exposure [26] with yield estimates in the region of $10^{10}$ molecules per laser shot made in the literature [27]. This discussion is valid in terms of the desorption/ ionization process, as every ion impact in a SIMS analysis can be treated as an independent event. However, if one were to compare the techniques from the point of view of secondary ions per pulse, it must be remembered that a single ion beam pulse in SIMS will contain in the order of $10^{3}$ ions.

When we contemplate the fate of a molecule on a surface during a SIMS event, it is certain that if it has been desorbed then it has received a collision, that is, contact with a neighboring molecule of greater intensity than the normal thermal movement of a solid. There will be an array of species emitted from the surface, some from the site of the primary impact with high internal energies and rapidly torn apart yielding electrons, protons, small fragments and elemental ions. Others will be desorbed from areas remote of this collision, "lifted" from the surface by the relatively gentle upward collision cascades [24]. It is these intact molecules with low internal energy that are the richest source of information for static SIMS. As it is only charged molecular species that are detected, the source of these ionic species is an important factor. Studies of amino acids on metal substrates have shown that the existence of ions in a precharged state, [28] with the molecular ion present in the surface with a counter ion explaining the experimental results. Langmuir-Blodgett films of acids and amines also lend support to the importance of preformed ions in certain systems [29]. However, this model is not supported in every system, such as the explanation of ions from multilayer films of neutral molecules. If the species is not present in the surface in a precharged form then the charge must be obtained at, or very near, the surface, and as with any system there must be laws that govern these movements.

The desorption/ionization model suggested by Cooks and Busch separates the desorption and ionization steps [30] ̈̈̈tatingḋhatähereösönoönetöreationø̈föons during the desorption, and that any neutral molecules in the selvedge (near surface area) or in the gas phase may be ionized by reaction with an electron or a desorbed ion. It is here that the relative proton affinity or gas-phase basicity of a molecule could be all-important. One of the chemical reactions identified by Detter et al. that occur at the vacuum and condensed phase interface are Brönsted acid-base reac-

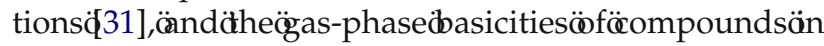
mixtures have already been shown to be important in fastäatomöbombardmentö(FAB) đ̈[32].đ̈ffötheösameäsötrue within SIMS, then within binary mixtures, the probability that a molecule is detected as a $[\mathrm{M}+\mathrm{H}]^{+}$or $[\mathrm{M}-$ $\mathrm{H}]^{-}$ion should be linked to these properties. By creating mixtures of compounds of known gas-phase basicities and studying the ions that are detected we aim to determine the role that these chemical properties play in the outcome of a SIMS experiment.

\section{Experimental}

\section{Instrumentation}

All experiments were carried out on the Bio-TOF SIMSänstrumentäsödescribedölsewheređ33].Briefly, primary ion bombardment leads to the desorption of secondary ions from the surface under analysis. These secondary ions are accelerated to a reflectron type time of flight mass analyzer and detected using a multi channel plate detector with $21 \mathrm{keV}$ post acceleration.

The experiments were carried out with a $15 \mathrm{keV} \mathrm{Au}{ }^{+}$ primary ion beam, with the sample stage biased to $\pm 2500 \mathrm{~V}$, giving impact energies of $12.5 \mathrm{keV}$ for positive ion analysis and $17.5 \mathrm{keV}$ for negative ion analysis. The primary ion beam pulse width was $40 \mathrm{~ns}$, with a DC beam current of $\sim 1 \mathrm{nA}$.

To resolve any issues of sample charging, a lowenergy $(25 \mathrm{eV})$ electron flood gun was pulsed between each ion gun pulse. Three areas of each sample were analyzed, with each analysis conducted over a $400 \times$ 
$400 \mu \mathrm{m}$ area, the average of these analyses are those given in this manuscript.

\section{Sample Preparation}

All materials were obtained from Sigma-Aldrich (Poole, UK) and analyzed without further purification. Standard surfaces of the pure compounds, as well as mixtures of these compounds were analyzed following one of two sample preparation techniques. The first is the dried droplet method, where solutions of the compounds were prepared in a 1:1 vol/vol acetonitrile: water mixture at a concentration of $5 \times 10^{-2} \mathrm{~mol} \mathrm{dm}^{-3}$. For the mixed samples, aliquots of the relevant solutions were added together and thoroughly mixed. Following preparation, $5 \mu \mathrm{L}$ of the resulting solution was then pipetted onto a cleaned silicon shard, producing a homogenous layer upon evaporation of the solvent. For the investigations involving cytosine, thymine and barbituric acid, the samples were prepared in an identical way; however the solvent used was methanol.
The second method involved analyzing the samples in a pressed powder form. Here the samples were prepared by coarsely grinding the pure dry powder and then placing a suitable amount onto a piece of indium and pressed with a cleaned metal implement to create a flat surface for analysis. For the mixtures, the compounds were mixed in a 1:1 wt/wt ratio before grinding. Multiple samples were analyzed to ensure that sample heterogeneity did not influence the results.

\section{Results and Discussion}

Mixtures of GGH and THAP

Spectra were obtained from pure films of these two compounds,öwhichöareöshownöinöTableö1,ötoöidentify theöcharacteristicöpeaks.öFigureölaöshowsötheöpositive spectrum of the tri-peptide, glycine-glycine-histidine $(\mathrm{GGH})$, the major peaks of interest are the $[\mathrm{M}+\mathrm{H}]^{+}$at $m / z 270$, the two immonium ions relating to the amino acids, glycine at $m / z 30$ and histidine at $m / z 110$, and the

Table 1. The gas phase basicities of the compounds used in this investigation. These values will be used in the discussion of the observed results

\begin{tabular}{lcccc}
\hline & Molecular weight & Gas phase basicity \\
\hline \hline Glycine-glycine-histidine (GGH) & 269.26 & Structure
\end{tabular}

\section{2, 4, 6 trihydroxyacetophenone (THAP)}

168.15<smiles>CC(=O)c1c(O)cc(O)cc1O</smiles>

Cytosine

111.10<smiles>Nc1cc[nH]c(=O)n1</smiles>

Thymine

126.11<smiles>Cc1c[nH]c(=O)[nH]c1=O</smiles>

Barbituric acid (BA)

128.09
$850 \mathrm{~kJ} / \mathrm{mol}[23]$

$918 \mathrm{~kJ} / \mathrm{mol}[35]$

$841 \mathrm{~kJ} / \mathrm{mol}$ [35]

$782 \mathrm{~kJ} / \mathrm{mol}$ [36] 


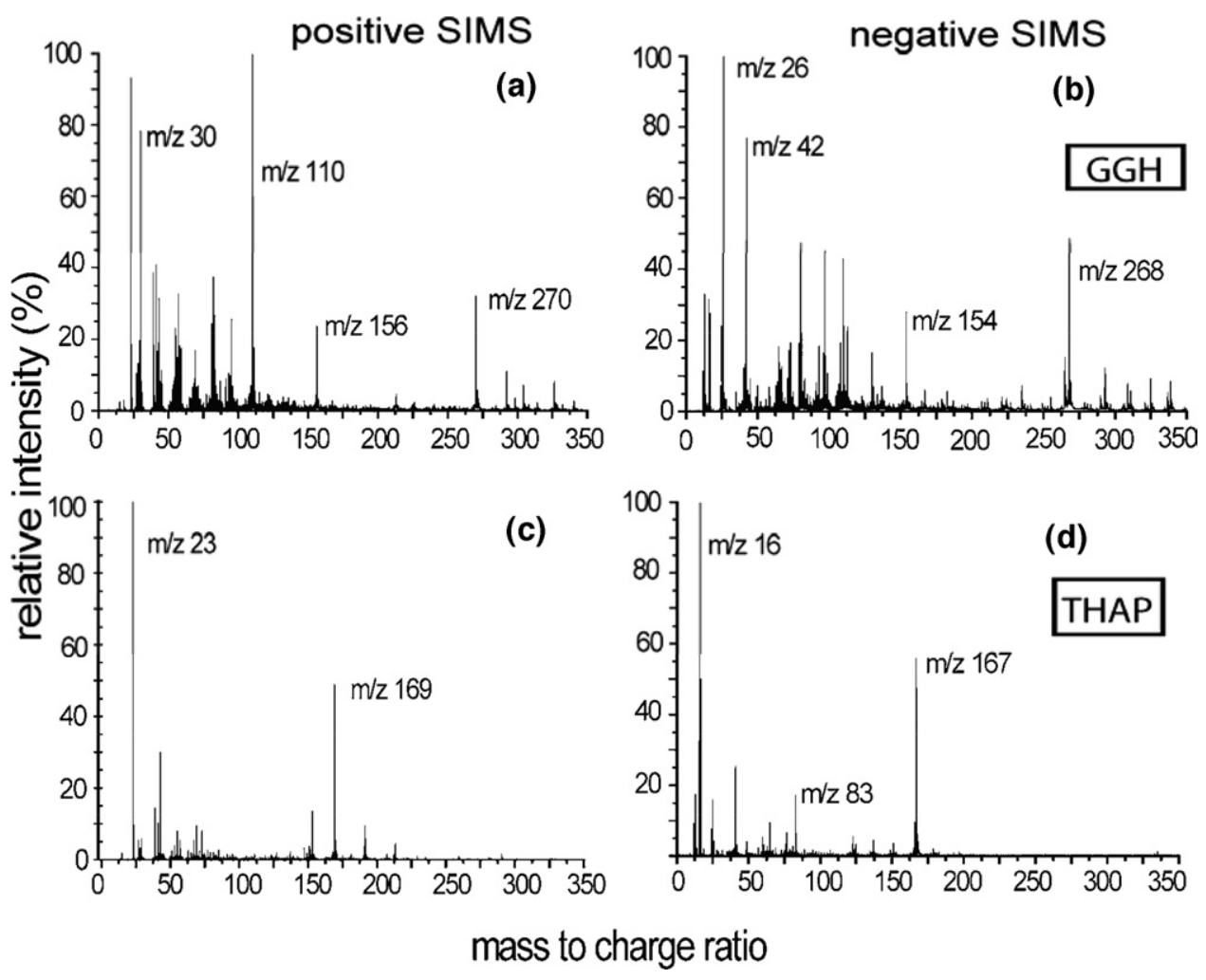

Figure 1. (a) Positive spectrum of GGH; (b) negative spectrum of GGH; (c) positive spectrum of THAP; (d) negative spectrum of THAP. All samples prepared as dried droplets on silicon.

protonatedöonöföhistidineätön/z 156.đ̈Figureölböhows the negative spectrum of the tripeptide with $\mathrm{m} / \mathrm{z} 268$ attributed to the $[\mathrm{M}-\mathrm{H}]^{-}$ion, as well as the deprotonated ion from histidine at $\mathrm{m} / \mathrm{z} 154$.

Inö Figureö 1c,ö theö positiveö spectrumö ofö 2,4,6trihydroxyacetophenone (THAP), the $\left[\mathrm{M}+\mathrm{H}^{+}{ }^{+}\right.$is seen at $m / z 169$ and the sodium adduct $[\mathrm{M}+\mathrm{Na}]^{+}$at $m / z 191$. TheönegativeöspectrumöoföTHAPö(Figureöld)öcontains the $[\mathrm{M}-\mathrm{H}]^{-}$ion at $m / z 167$.

Mixtures of the solutions of the tripeptide (GGH) and the matrix (THAP) were prepared in a 1:1 $\mathrm{M}$ ratio and used to form films on cleaned silicon via the dried droplet method. This combination of compounds was chosen to replicate the experiments performed by the Zenobiögroupö[23]öwhereösignificantömatrix/analyte suppression was observed and rationalized in the MALDI analysis. Because the gas-phase basicities of theseöcompoundsöareöknownö(Tableö1),ötheyöcouldöbe incorporated into the discussion of the ionization mechanismsöoccurringöwithinöheösystem.öFromöFigureä2a,ät is observed that there is a suppression effect occurring within the SIMS analysis. The $[\mathrm{M}+\mathrm{H}]^{+}$ion of the
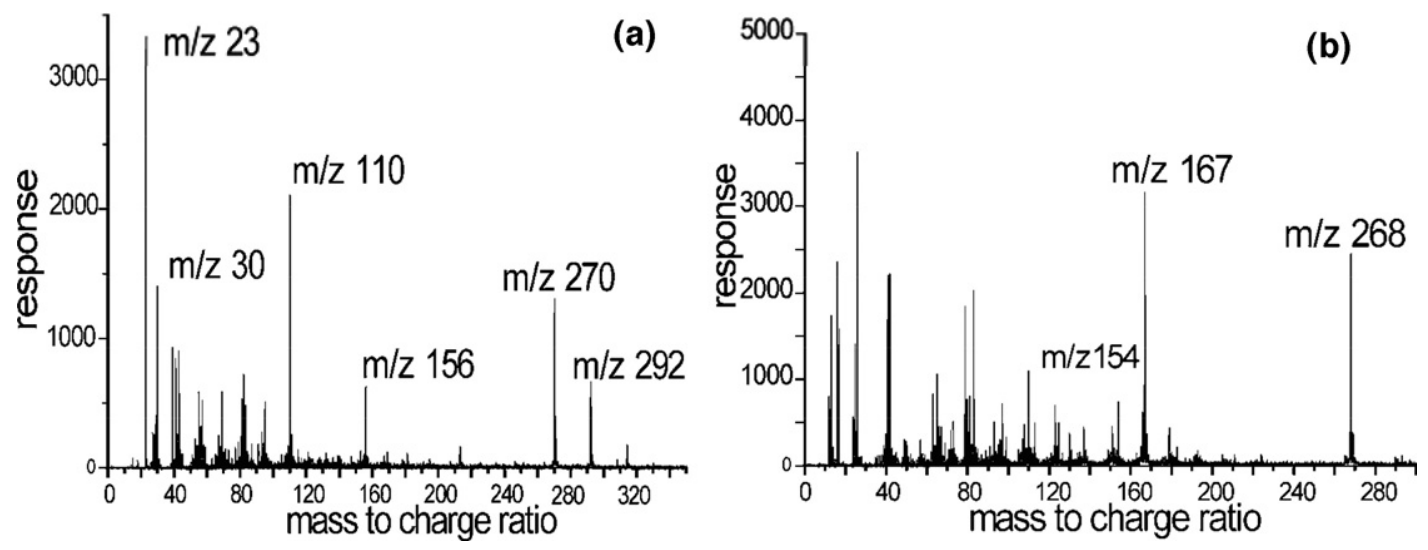

Figure 2. (a) Positive spectrum of a 1:1 mixture of THAP and GGH formed by the dried droplet method; (b) negative spectrum of the same area. The characteristic ions for the THAP are only present in the negative spectrum. 
THAP is not detected even though the $[\mathrm{M}-\mathrm{H}]^{-}$ion is present in the negative spectrum at a high abundance

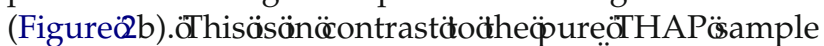

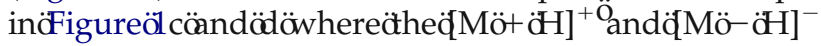
ions are of similar intensity. Clearly, the presence of the GGH has altered the probability of either the formation or survival of protonated THAP species during the SIMS event.

An explanation for the suppression of the $[\mathrm{M}+\mathrm{H}]^{+}$ ion of the THAP molecule can be suggested based on ion molecule interactions. By using the gas-phase basicityövaluesöinöTableö1,öeqö1öcanöbeöcalculated.öThis suggests that any collisions between the neutral tripeptide and a protonated THAP molecule will strongly favor a transfer of the proton to the tripeptide.

$$
\begin{gathered}
\mathrm{GGH}+[\mathrm{THAP}+\mathrm{H}]^{+} \rightarrow[\mathrm{GGH}+\mathrm{H}]^{+}+\mathrm{THAP} \\
\Delta \mathrm{G}-129 \mathrm{~kJ} / \mathrm{mol}
\end{gathered}
$$

However,äunlikeöheöMALDIöexperimentđ̈[23],ätheösuppression of the $[\mathrm{GGH}-\mathrm{H}]^{-}$ion is not seen here. Through imaging the surface (not shown) it was seen that the $[\mathrm{M}-\mathrm{H}]^{-}$of THAP and GGH are detected from the same areas of the sample, ruling out distinct chemical domains. As precise values for the gasphase basicities of the $[\mathrm{M}-\mathrm{H}]^{-}$ion of both the GGH and THAP are not available, it is not possible to calculate the exact energies involved in eq 2. However,öfromöestimatesömadeöinöreferenceö[23],öitöis postulated that the endoergicity is less than $75 \mathrm{~kJ} /$ mol, and hence the formation of the $[\mathrm{GGH}-\mathrm{H}]^{-}$is restricted by an energy barrier that equates to $0.78 \mathrm{eV}$, which could be accounted for by the internal energy of the molecule.

$$
\begin{gathered}
\mathrm{GGH}+[\mathrm{THAP}-\mathrm{H}]^{-} \rightarrow[\mathrm{GGH}-\mathrm{H}]^{-}+\mathrm{THAP} \\
\Delta \mathrm{G}<+75 \mathrm{~kJ} / \mathrm{mol}
\end{gathered}
$$

Additionally, as the internal energy of the desorbed species increase, so therefore does the probability of fragmentation occurring within the vacuum as the molecules dissipate the excess energy through bond fissions. One product of such action could be the deprotonated molecular species. These dissociations away from the surface may be the significant pathway to the $[\mathrm{M}-\mathrm{H}]^{-}$of the $\mathrm{GGH}$ and hence the yield of these ions is not greatly affected by the surface chemistry.

The other possible source of these ions could be due to solution phase chemistry leading to the presence of ionized species within the liquid, which may prevail as the solvent evaporates to form the solid surface. The presence of both an amino group and a carboxylic group on the tripeptide may lead to the formation of preformed ions of both ion polarities within the sample, whilst the acidic matrix largely favors the formation of $[\mathrm{M}-\mathrm{H}]^{-}$ions following solution phase reactions.

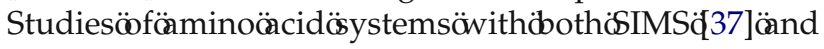
laserö desorptionö ionizationö massö spectrometryö [38] demonstrate, through the use of deuterium in place of the labile hydrogen atoms, that it is these atoms that are transferred to form the ions seen, and, thus, supporting the solution phase proton transfer theory. The SIMS analysis of a selection of compounds with a range of $\mathrm{pKa}$ values, deposited onto silver from solutions with varying $\mathrm{pH}$, demonstrated a strong relationship between the intensity of the $[\mathrm{M}+\mathrm{H}]^{+}$ion and the relative pHäoọ̈Kaöratioöffäheösolutionändönalyteđ39].đ̈töwas suggested that ions formed in solution could conserve their ionic state during the evaporation of the solvent, and therefore that solution phase chemistry may dictate the ions observed in the analysis.

\section{GGH and THAP as Pressed Powder Sample}

By creating a powder mixture of THAP and GGH which had been ground together before being pressed into an indium substrate, the importance of solution phase chemistry can be assessed. With this method of preparation, it should be fair to assume that the sample will be far from homogeneous on the molecular level due to incomplete mixing. On a local scale, many molecules will be adjacent only to molecules of the same compound, although on a larger scale the surface should appear as a homogeneous mixture.

Nevertheless, if we are to accept that the majority of ions detected from a sample are due to preformed ions then we would expect this coarse mixture to more closely resemble an overlapping of the spectra from the two compounds, with the most noticeable effect being the presence of the $[\mathrm{M}+\mathrm{H}]^{+}$ion of the THAP in the positiveö spectra.ö Figureö 3 ö showsö theö spectralö area around the quasi-molecular peak of THAP in a pure THAP powder sample and in a 1:1 wt/wt powder mixture with the tripeptide GGH. Here, as with the samples prepared from solution, we see the dramatic

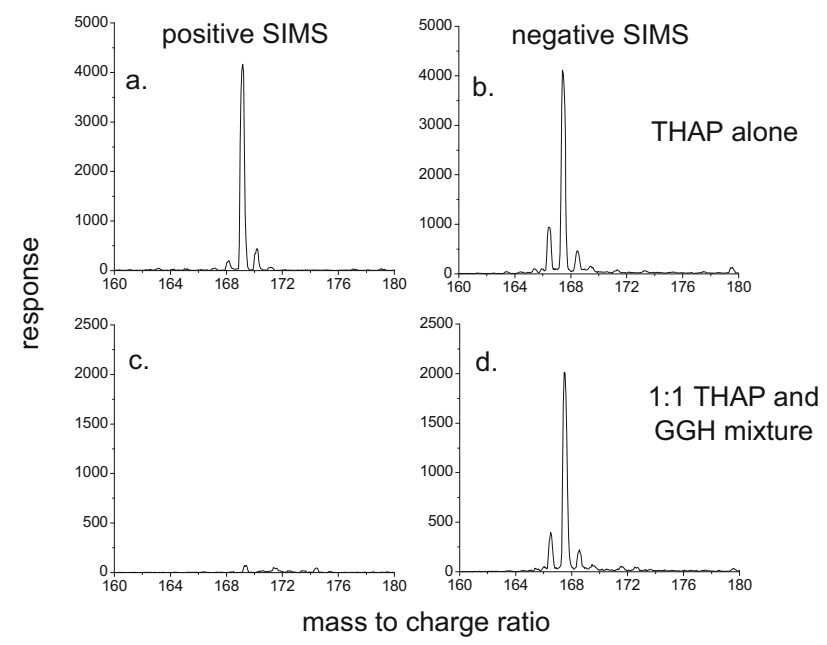

Figure 3. The quasi-molecular ion region of THAP in both positive and negative ion modes in two different pressed powder samples. (a) and (b) a pure surface of THAP; (c) and (d) a 1:1 mixture with the tripeptide GGH. 
Table 2. The ratio of protonated to deprotonated molecular ions from pure films and from 1:1 mixtures of THAP with compounds of varying gas phase basicity

\begin{tabular}{lccccccc}
\hline & $\begin{array}{c}\text { Pure } \\
\text { THAP }\end{array}$ & $\begin{array}{c}\text { Pure } \\
\text { cytosine }\end{array}$ & $\begin{array}{c}\text { Pure } \\
\text { thymine }\end{array}$ & Pure BA & Cytosine/THAP & Thymine/THAP & BA/THAP \\
\hline \hline $\begin{array}{l}{[\mathrm{M}+\mathrm{H}]^{+} /[\mathrm{M}-\mathrm{H}]^{-} \text {THAP }} \\
{[\mathrm{M}+\mathrm{H}]^{+} /[\mathrm{M}-\mathrm{H}]^{-} \text {other }} \\
\text { component }\end{array}$ & 0.9 & - & 3.1 & 1.1 & 0.5 & $0.02^{*}(2 \%)$ & $0.73(81 \%)$ \\
$43(1390 \%)$ & $1.4(127 \%)$ & $0.08(6 \%)$ \\
\hline
\end{tabular}

*The figures in the parenthesis refer to the difference between the $[\mathrm{M}+\mathrm{H}]^{+} /[\mathrm{M}-\mathrm{H}]$ values for the compounds when analyzed in the mixture as opposed to the pure sample.

suppression of the $[\mathrm{M}+\mathrm{H}]^{+}$ion of THAP in the positive spectrum. When the $[\mathrm{M}+\mathrm{H}]^{+} /[\mathrm{M}-\mathrm{H}]^{-}$ values of the THAP molecule are compared from the pure powder sample (ratio 0.9) to this powder mixture (ratio 0.06) clearly even without solution phase chemistry there is a significant suppression of the protonated species. However, as seen with the samples prepared from solution, the $[\mathrm{M}+\mathrm{H}]^{+} /[\mathrm{M}-\mathrm{H}]^{-}$ratio for the tripeptide does not show a significant change in the ion distribution when compared with the pure samples and, thus, there is seemingly no complementary effect to the suppression of the THAP $[\mathrm{M}+\mathrm{H}]^{+}$ion in the negative ion spectra.

The fact that the results from these two different sample preparation techniques are very similar, in terms of the ions present, suggests that the factors determining the ions that are detected occur after the impact of the primary ion. In addition, it has been shown that there must be a large degree of mixing within the perturbed region of the sample, which is in agreement withöpreviousöworköonösimilarösampleäypesđ̈40].

\section{DNA Bases and THAP}

If the acid/base properties of the THAP and GGH mixture cause the suppression of the $[\mathrm{M}+\mathrm{H}]^{+}$ion of the THAP, then it could be postulated that when mixed with a compound of lower gas-phase basicity the [M + $\mathrm{H}]^{+}$ion could be favored. Unfortunately, the gas-phase basicity of the least basic amino acid, glycine is 852 $\mathrm{kJ} / \mathrm{mol}$ [34],öwhichösäpproximatelÿ̈qualḋođhatöfd̈he THAP molecule. Therefore, for the continuation of this study the bio-molecules that will be used are the DNA nucleobases cytosine and thymine, and the structurally

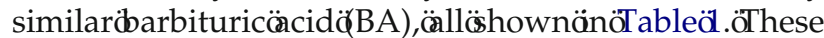
compounds have gas-phase basicities of 918, 841 and 782ökJ/molörespectivelyö[35,ö36]öandöthusöprovideöa suitable range to allow the behavior of the THAP molecule within mixtures to be further investigated.

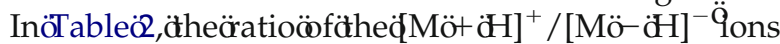
for the molecules involved are listed for a pure sample and within the mixtures. These results demonstrate that, in agreement with the tripeptide gly-gly-his sample, the mixture of THAP and cytosine (which has a higher gas-phase basicity) favors of the $[\mathrm{M}-\mathrm{H}]^{-}$ion for the THAP molecule, indicated by the low value for the $[\mathrm{M}+\mathrm{H}]^{+} /[\mathrm{M}-\mathrm{H}]^{-}$ratio. With thymine, a compound of similar gas-phase basicity, the ratio is equivalent to the pure sample. This suggests that neither direction of proton transfer is completely dominant over the other. In the sample where the THAP was mixed with barbituric acid, a molecule of lower gasphase basicity, the protonated form of the THAP molecule is favored. As this is the only case where the $[\mathrm{M}+$
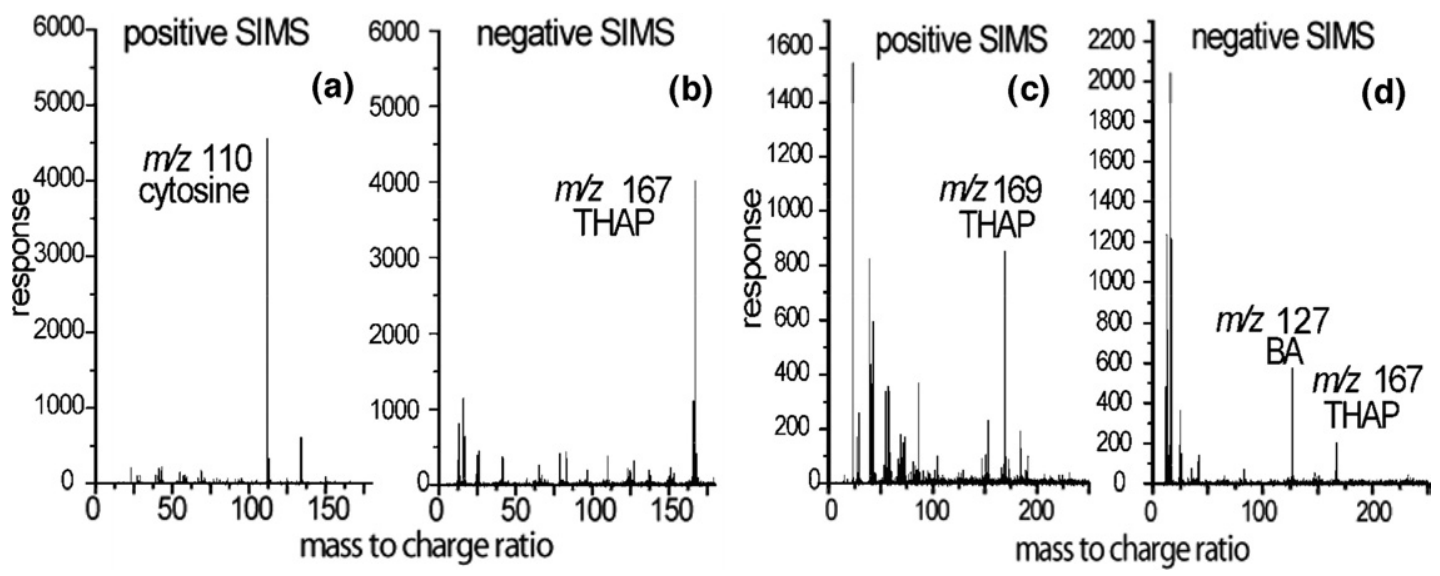

Figure 4. (a) and (b) 1:1 mixture of THAP and cytosine, demonstrating the gas-phase basicity of the molecules within the mixture dictate the ion polarity in which the quasi-molecular ion will be detected; (c) and (d) 1:1 mixture of THAP with barbituric acid, demonstrating that by mixing the THAP molecule with a compound of lower gas-phase basicity the $[\mathrm{M}+\mathrm{H}]^{+}$ion, which is suppressed in the previous example, can become the favored ion. 

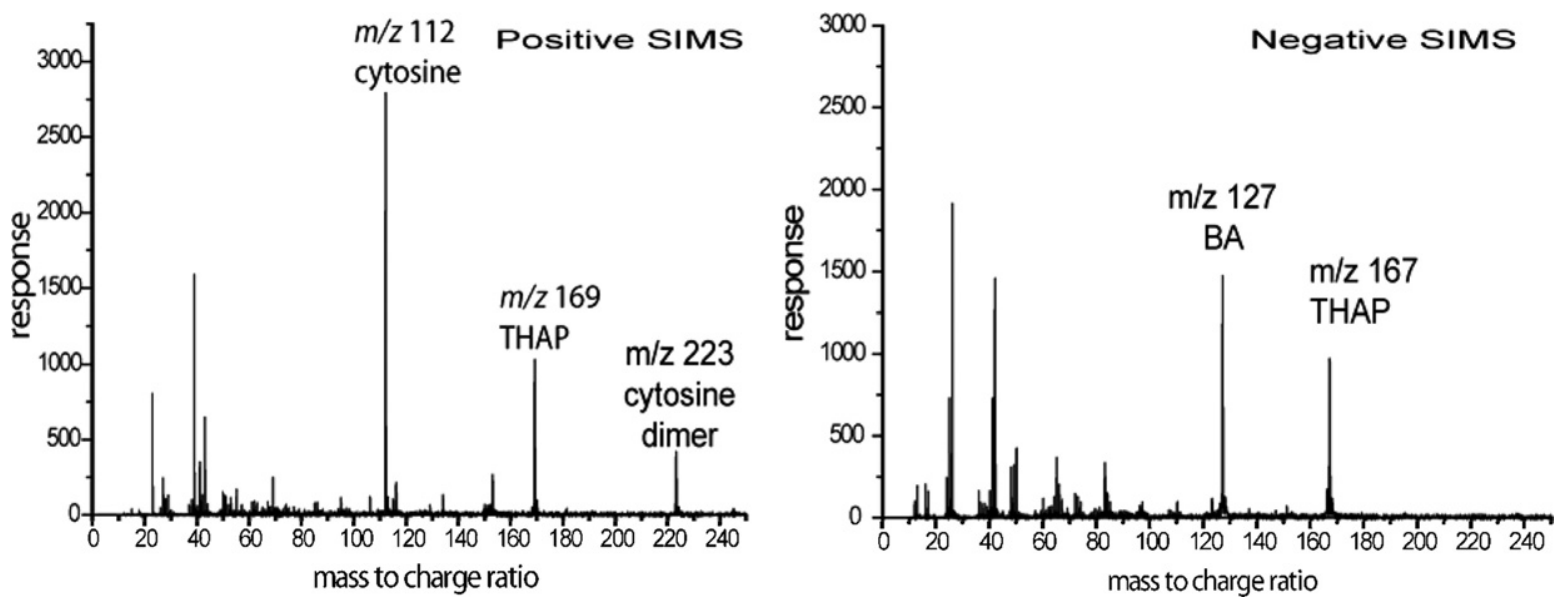

Figure 5. The positive and negative spectra of a 1:1:1 M mixture of THAP, cytosine, and barbituric acid. In the presence of both a compound of higher and lower gas-phase basicities the quasi-molecular ion distribution of the THAP molecule is very similar to that from a pure spectrum.

$\mathrm{H}]^{+}$yields a stronger signal than the $[\mathrm{M}-\mathrm{H}]^{-}$for the THAP, the importance of gas-phase basicity to the proton transfer direction within mixtures is strongly supported here.

TheöresultsönöTableä2ölsoödemonstrateähatäheöquasimolecular ions of the other component in the mixture behaves in a complementary fashion to the THAP molecule, with the $[\mathrm{M}+\mathrm{H}]^{+}$of cytosine and the $[\mathrm{M}-\mathrm{H}]^{-}$ ofötheöbarbituricöacidöbeingöfavoured.öFigureöłöshows the positive and negative ion spectra from both the 1:1 THAP:äcytosineä(Fig.öłaäandöb)ëandöTHAP:ة̈BÄ̈Fig.öłc and d) mixtures, respectively. These samples demonstrate almost complete suppression of the respective molecules in the two polarities as predicted from the acid/base properties of the molecules. Unfortunately, there are no values available for the gas-phase basicity of the $[\mathrm{M}-\mathrm{H}]^{-}$of the compounds present in the mixtures with THAP in this section, therefore the energetics of the negative ion formation cannot be calculated. However, the fact that there is complementary suppression of the two constituents of the mixture, one in the positive polarity the other in negative, suggests that the energetics and also the collision density within the emission zone are such that the species predicted by the gas-phase basicities are those that make up the majority of quasi-molecular signal detected.

\section{Three-Component Mixture}

TheöexampleänöFigureöłaöandöbödemonstrateötheödramatic suppression of the quasi-molecular ions of both components in a mixture containing cytosine and THAP, due to the transfer of protons within the system being strongly favoured in a given direction, dictated by the chemical properties of the molecules involved. To investigate whether the effect of this suppression can be influenced by a third molecule, THAP was analyzed once more, this time in a 1:1:1 M mixture of THAP, cytosine and barbituric acid. The spectra presented in
Figureö5ödemonstrateöthatöwhenöthisömixtureöisöanalyzed, the positive ion spectrum shows the quasimolecular ions of cytosine and THAP, whilst the negative ion spectrum has the quasi-molecular ions of THAP and barbituric acid.

If the three-component mixture is compared with the THAPändöytosineömixtureöshownönđ̈Figureäłaöndd̈, it is shown that the addition of a third molecule can negate the suppression effect, and as demonstrated in

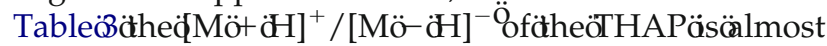
identical to that seen in the pure sample. Contrary to this, both the cytosine and barbituric acid show almost an order of magnitude difference to the pure samples, the cytosine favoring the protonated species, the barbituric acid the deprotonated quasi-molecular ion.

This result can be rationalized in terms of the overall reaction sequence occurring within the surface region. In the two-component mixture, any interactions between the THAP molecules and another species favor the transfer of a proton to the cytosine molecule. Within the three-component system it may be expected that a THAP molecule involved in a SIMS event will potentially form either the $[\mathrm{M}+\mathrm{H}]^{+}$or $[\mathrm{M}-\mathrm{H}]^{-}$ion depending upon which other species it encounters, which appears to be the case from the data. By using this argument it would be expected that the cytosine molecule should accept a proton from both the THAP and BA molecular ions so will strongly favor the $[\mathrm{M}+$ $\mathrm{H}]^{+}$ion, with the converse true of the BA.

Table 3. Ratio of protonated to deprotonated molecular ions for cytosine, THAP and barbituric acid (BA) from pure samples and the three-component 1:1:1 mixture

\begin{tabular}{lcc}
\hline & $\begin{array}{c}{[\mathrm{M}+\mathrm{H}]^{+} /[\mathrm{M}-\mathrm{H}]} \\
\text { in a pure sample }\end{array}$ & $\begin{array}{c}{[\mathrm{M}+\mathrm{H}]^{+} /[\mathrm{M}-\mathrm{H}] \text { from the }} \\
\text { three component mixture }\end{array}$ \\
\hline \hline Cytosine & 3.1 & 36 \\
THAP & 0.9 & 1.1 \\
BA & 0.5 & 0.07 \\
\hline
\end{tabular}




\section{Conclusions}

Zenobiöetäl.đ22]ödescribeäheömportanceöfösecondary reactions to the outcome of ions detected in a MALDI event; these secondary reactions are ion molecule collisions within the expanding plume of desorbed material. As stated in the introduction it is suspected that the sputter plume in SIMS is not large enough to allow a thermodynamic equilibrium to be reached within the desorbed material. However, as demonstrated in this work, the population of ions that are desorbed from a binary or tertiary mixture under SIMS analysis is dependant upon the chemical properties of compounds within the mixture. The propensity of a molecule to form either a protonated or deprotonated ion depends upon the relative acid/base properties of the compounds present, which dictate the direction of proton transfer in ion molecule reactions. Knowledge of the gas-phase basicities of the compounds analyzed has allowed the transfer of protons within the experiments to be explained. Although the amount of material sputtered in a SIMS event can be as low as tens of molecules, the number of interactions within the solid and expanding surface following primary ion impact is sufficient to allow the detected ion population to reflect the properties of the compounds present.

As the applications of static-SIMS widens, dealing with increasingly complex sample types, the consequences of matrix effect on the ions detected must be an important consideration for the analyst. In a multidomain sample, there is a significant possibility the same analyte may be detected with varying success due to differences in the chemical environments. This is particularly relevant to biological samples where various chemical domains exist within a single tissue section and, in many cases, the molecule of interest will be in a low abundance.

The results reported here highlight the care that must be taken when reporting results from complex samples, especially for images. A molecule distributed homogeneously across a surface may be detected with very different intensity from one region to another, solely due to differences in the chemical composition of these areas. Such results have been demonstrated in both

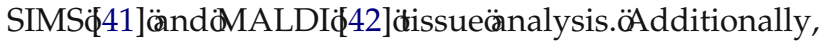
in certain circumstances, the compound responsible for the variation in ionization probability may have its signal suppressed in that ion polarity and, hence, not be detected. It is for this reason that it is important that data be collected for the same sample in both polarities.

To have confidence in the distribution shown for a target molecule in a SIMS image of a complex surface, the use of model systems and normalization as discussedöbyöStoeckliöetöal.ö[42]öisöoneöpossibleömethod. However, this is a long-winded approach and removes a novel feature of imaging mass spectrometry, that of demonstrating the distribution of many molecules within the same sample. Another possibility is to lessen the contribution of the native compounds to the ioniza- tion process, whilst creating a near heterogeneous chemical environment from all regions of the sample.

The three-component experiments demonstrated that the suppression of the [THAP $+\mathrm{H}^{+}$ion by a compound of higher gas-phase basicity could be negated by the presence of a compound of significantly lower gas-phase basicity. Although ideally, the amount of alteration a sample undergoes before analysis should be kept low to ensure the system is in as native a state as possible, approaches such as matrix deposition may well reduce the variance in the ionization probabilities of a given analyte across a heterogeneous sample, if they initiated dominant ionization pathways. Within biological samples, a suitable "matrix" molecule may already be present, water. With a high abundance, and a gas-phase basicity of $660 \mathrm{~kJ} / \mathrm{mol}$, analyzing cells and tissue in a frozen hydrated form would ensure an abundant amount of matrix molecules that could be an important source of protons, without having to disrupt the native chemistry of the sample. Recent work from thisögroupösupportsöthisöpropositionö[43],öandöitöisöan area of ongoing interest.

\section{Acknowledgments}

The authors gratefully acknowledge the financial support of the U.K. Engineering and Physical Sciences Research Council-Life Sciences Interface Programme (EPSRC-LSI).

\section{References}

1. Pacholski, M. L.; Cannon, D. M., Jr.; Ewing, A. G.; Winograd, N. Static Time-of-flight Secondary Ion Mass Spectrometry Imaging of Freezefractured, Frozen-Hydrated Biological Membranes. Rapid Commun. Mass Spectrom. 1998, 12, 1232-1235.

2. Todd, P. J.; McMahon, J. M.; Short, R. T.; McCandlish, C. A. Organic SIMS of Biological Tissue. Anal. Chem. 1997, 69, 529A-535A.

3. Davis, N.; Weibel, D. E.; Blenkinsopp, P.; Lockyer, N.; Hill, R.; Vickerman, J. C. Development and Experimental Application of a Gold Liquid Metal Ion Source. Appl. Surf. Sci. 2003, 203/204, 223-227.

4. Kollmer, F. Cluster Primary Ion Bombardment of Organic Materials. Appl. Surf. Sci. 2004, 231/232, 153-158.

5. Weibel, D.; Wong, S.; Lockyer, N.; Blenkinsopp, P.; Hill, R.; Vickerman, J. C. $\mathrm{A} \mathrm{C}_{60}$ Primary Ion Beam System for Time of Flight Secondary Ion Mass Spectrometry: Its Development and Secondary Ion Yield Characteristics. Anal. Chem. 2003, 75, 1754-1764.

6. Wu, K. J.; Odom, R. W. Matrix-Enhanced Secondary Ion Mass Spectrometry: A Method for Molecular Analysis of Solid Surfaces. Anal. Chem. 1996, 68, 873-882.

7. Delcorte, A.; Medard, N.; Bertrand, P. Organic Secondary Ion Mass Spectrometry: Sensitivity Enhancement by Gold Deposition. Anal. Chem. 2002, 74, 4955-4968.

8. Altelaar, A. F. M.; Van Minner, J.; Jiménez, C. R.; Heeren, R. M. A. Piersma, S. R. Direct Molecular Imaging of Lymnaea stagnalis Nervous Tissue at Subcellular Spatial Resolution by Mass Spectrometry. Anal. Chem. 2005, 77, 735-741.

9. Altelaar, A. F. M.; Klinkert, I.; Jalink, K.; de Lange, R. P. J.; Adan, R. A. H.; Heeren, R. M. A.; Piersma, S. R. Gold-Enhanced Biomolecular Surface Imaging of Cells and Tissue by SIMS and MALDI Mass Spectrometry. Anal. Chem. 2006, 78, 734-742.

10. McDonnell, L. A.; Piersma, S. R.; Maarten Altelaar, A. F.; Todd, H.; Luxembourg, S. L.; Verhaert, P. D. E. M.; Van Minnen, J.; Heeren, R. M. A. Subcellular Imaging Mass Spectrometry of Brain Tissue. J. Mass Spectrom. 2005, 40, 160-168.

11. Nygren, H.; Malmberg, P.; Kriegeskotte, C.; Arlinghaus, H. F. Bioimaging TOF-SIMS: Localization of Cholesterol in Rat Kidney Sections. FEBS Lett. 2004, 566, 291-293.

12. Sjoevall, P.; Lausmaa, J.; Johansson, B. Mass Spectrometric Imaging of Lipids in Brain Tissue. Anal. Chem. 2004, 76, 4271-4278.

13. Touboul, D.; Halgand, F.; Brunelle, A.; Kersting, R.; Tallarek, E. Hagenhoff, B.; Laprevote, O. Tissue Molecular Ion Imaging by Gold Cluster Ion Bombardment. Anal. Chem. 2004, 76, 1550-1559.

14. Nygren, H.; Boerner, K.; Hagenhoff, B.; Malmberg, P.; Mansson, J.-E Localization of Cholesterol, Phosphocholine, and Galactosylceramide in 
Rat Cerebellar Cortex with Imaging TOF-SIMS Equipped with a Bismuth Cluster Ion Source. Biochim. Biophys. Acta. 2005, 1737, 102-111.

15. Touboul, D.; Kollmer, F.; Niehuis, E.; Brunelle, A.; Laprevote, O. Improvement of Biological Time-of-Flight-Secondary Ion Mass Spectrometry Imaging with a Bismuth Cluster Ion Source. J. Am. Soc. Mass Spectrom. 2005, 16, 1608-1618.

16. Wittmaack, K: Szymczak, W.; Hoheisel, G. Tuszynski, W. Time-ofFlight Secondary Ion Mass Spectrometry of Matrix-Diluted Oligo- and Polypeptides Bombarded with Slow and Fast Projectiles: Positive and Negative Matrix and Analyte Ion Yields, Background Signals, and Sample Aging. I. Am. Soc. Mass Spectrom. 2000, 11, 553-563.

17. Adriaensen, L.; Vangaever, F.; Lenaerts, J.; Gijbels, R. Matrix-Enhanced Secondary Ion Mass Spectrometry: The Influence of MALDI Matrices on Molecular Ion Yields of Thin Organic Films. Rapid Commun. Mass Spectrom. 2005, 19, 1017-1024.

18. Karas, M.; Bachmann, D.; Bahr, U.; Hillenkamp, F. Matrix-Assisted Ultraviolet Laser Desorption of Nonvolatile Compounds. Int. J. Mass Spectrom. Ion Processes 1987, 78, 53-68.

19. Karas, M.; Hillenkamp, F. Laser Desorption Ionization of Proteins with Molecular Masses Exceeding 10, 000 Daltons. Anal. Chem. 1988, 60, 2299-2301.

20. Tanaka, K.; Waki, H.; Ido, Y.; Akita, S.; Yoshida, Y.; Yoshida, T. Protein and Polymer Analysis up to $m / z 100,000$ by Laser ionization time of flight mass spectrometry. Rapid Commun. Mass Spectrom. 1988, 2, 151-153.

21. Zenobi, R.; Knochenmuss, R. Ion formation in MALDI mass spectrometry. Mass Spectrom. Rev. 1998, 17, 337-366.

22. Knochenmuss, R.; Zenobi, R. MALDI Ionization: The Role of in Plume Processes. Chem. Rev. 2003, 103, 441-452.

23. Breuker, K.; Knochenmuss, R.; Zhang, J.; Stortelder, A.; Zenobi, R. Thermodynamic Control of Final Ion Distributions in MALDI: In-Plume Proton Transfer Reactions. Int. I. Mass Spectrom. 2003, 226, 211-222.

24. Vickerman, J. C.; Briggs, D., Eds. In: TOF-SIMS: Surface Analysis by Mass Spectrometry; IM Publications and Surface Spectra Limited: Charlton, Chichester, West Sussex, UK, 2001; pp. 1-21.

25. Wucher, A.; Sun, S.; Szakal, C.; Winograd, N.; Molecular Depth. Profiling of Histamine in Ice Using a Buckminsterfullerene Probe. Anal. Chem. 2004, 76, 7234-7242.

26. Kampmeier, J.; Dreisewerd, K.; Schurenberg, M.; Strupat, K. Investigations of 2,5-DHB and succinic acid as matrices for IR and UV MALDI Part 1. UV and IR ablation in the MALDI process. Int. J. Mass Spectrom. Ion Processes 1997, 169/170, 31-41.

27. Garrison, B. J. Atoms, Clusters, and Photons: Energetic Probes from Mass Spectrometry. Appl. Surf. Sci. 2006, 252, 6409-6412.

28. Benninghoven, A. Some Aspects of Secondary Ion Mass Spectrometry of Organic Compounds. Int. J. Mass Spectrom. Ion Phys. 1983, 53, 85-99.

29. Li, J. X.; Gardella, J. A., Jr.; McKeown, P. J. A Quantitative Time-ofFlight Secondary Ion Mass Spectrometry Study of Ion Formation
Mechanisms Using Acid-Base Alternating Langmuir-Blodgett Films. Appl. Surf. Sci. 1995, 90, 205-215.

30. Cooks, R. G.; Busch, K. L. Matrix Effects, Internal Energies, and MS/MS Spectra of Molecular Ions Sputtered from Surfaces. Int. J. Mass Spectrom. Ion Phys. 1983, 53, 111-124.

31. Detter, L. D.; Hand, O. W.; Cooks, G.; Walton, R. A. Interfacial Chemical Reactions Accompanying Desorption Ionization Mass Spectrometry. Mass Spectrom. Rev. 1988, 7, 465-502.

32. Sunner, J. A.; Kulatunga, R.; Kerbarle, P. Fast Atom Bombardment and Gas-Phase Basicities, Anal. Chem. 1986, 58, 1312-1316.

33. Braun, R. M.; Blenkinsopp, P.; Mullock, S. J.; Corlett, C.; Willey, K. F. Vickerman, J. C.; Winograd, N. Performance Characteristics of a Chemical Imaging Time-of-Flight Mass Spectrometer. Rapid Commun. Mass Spectrom. 1998, 12, 1246-1252.

34. Hunter, E. P. L.; Lias, E. G. Evaluated Gas-Phase Basicities and Proton Affinities of Molecules: An Update. J. Phys. Chem. Ref. Data 1998, 27, 413-656.

35. Russo, N.; Toscano, M.; Grand, A.; Jolibois, F. Protonation of Thymine, Cytosine, Adenine, and Guanine DNA Nucleic Acid Bases; Theoretical Investigation into the Framework of Density Functional Theory. J. Comput. Chem. 1998, 19, 989-1000.

36. Alvares, E. J.; Brodbelt, J. S. Comparison of the Gas-Phase Basicities and Relative Methylation Nucleophilicities of Carbonyl-Containing Compounds. J. Mass Spectrom. 1996, 31, 901-907.

37. Benninghoven, A. Static-SIMS Applications-From Silicon Single Crystal Oxidation to DNA Sequencing. J. Vac. Sci. Technol. 1985, 3, 451-460.

38. Novak, F. P.; Balasanmugan, K.; Viswanadham, K.; Parker, C. D.; Wilk, Z. A.; Mattern, D.; Hercules, D. M. Laser Induced Mass Spectrometry: Ion Formation Processes and Recent Developments. Int. J. Mass Spectrom. Ion Phys. 1983, 53, 135-149.

39. Inchaouh, J.; Blais, J. C.; Bolbach, G.; Brunot, A. Protonation in Organic Secondary Ion Mass Spectrometry: Correlation with Solution Chemistry Involved in Sample Preparation. Int. J. Mass Spectrom. Ion Processes 1984 61, 153-156.

40. Pachuta, S. J.; Cooks, R. G. Mechanisms in Molecular SIMS. Chem. Rev. 1987, 87, 647-669.

41. Jones, E. A.; Lockyer, N. P. Vickerman, J. C. Mass Spectral Analysis and Imaging of Tissue by TOF-SIMS-The Role of Buckminsterfullerene ${\mathrm{C} 60^{+}}$primary ions. Int. J. Mass Spectrom. 2007, 260, 146-157.

42. Stoeckli, M.; Staab, D.; Schweitzer, A. Compound and Metabolite Distribution Measured by MALDI Mass Spectrometric Imaging in Whole-Body Tissue Sections. Int. J. Mass Spectrom. 2007, 260, 195-202.

43. Conlan, X. A.; Lockyer, N. P.; Vickerman, J. C. Is Proton Cationization Promoted by Polyatomic Primary Ion Bombardment During Time-ofFlight Secondary Ion Mass Spectrometry Analysis of Frozen Aqueous Solutions? Rapid Commun. Mass Spectrom. 2006, 20, 1327-1334. 